\title{
WILLIAM HARVEY BECK, 1927-2002
}

\section{STUART HOUSTON, 863 University Drive, Saskatoon, SK S7N 0J8}

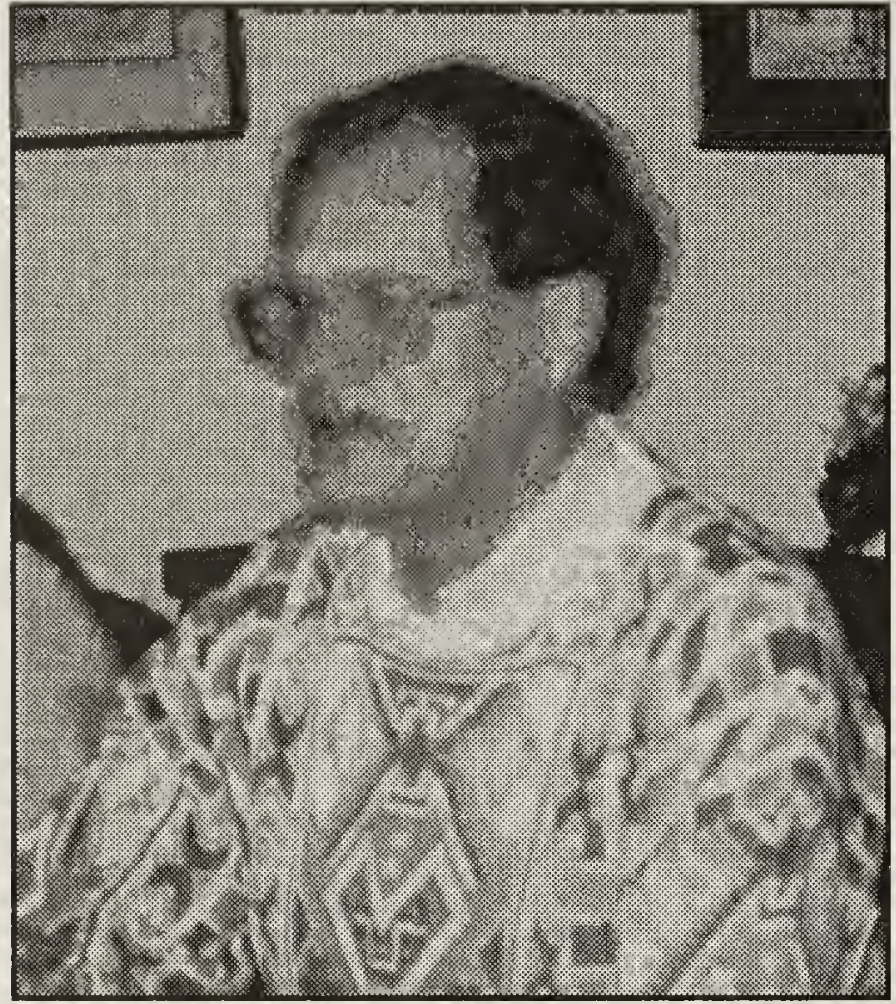

Photo by Pat Cradock

Harvey Beck was born in Yorkton on 14 September 1927. His mother was an English war bride and his parents were proprietors of a dry goods store. Harvey's abiding passion was entomology, hence he fell under the thrall of Isabel Priestly, and was one of the four high school participants at the inaugural meeting of the Yorkton Natural History Society. In the $50^{\text {th }}$ anniversary edition of Blue Jay, Harvey reported that Mrs. Priestly was "the first adult to treat me as an equal and one of the few adults with whom, as a teenager, I felt completely at ease." He served as a director for three years, until he left in 1945 to study biology at the University of Saskatchewan.

As an undergraduate student, during the summers of 1947 and 1948, he worked for J. G. Rempel on the University's insect collections. Dr. Rempel described him as "industrious, self-reliant, ... with unusual ability and enthusiasm for the meticulous kind of work required as a curator." Because mosquitos were believed to carry the virus of Western Equine Encephalitis, it became Rempel's priority, with Harvey's help, to collect specimens of every species of mosquito in Saskatchewan. While other people swatted mosquitos, Harvey let them land on his bare arm, studied them, and collected intact, with a vial and chloroform, those that might represent a new species.

To finance his education, Harvey spent a year at Teacher's College (then called Normal School), to gain a teaching diploma, and then taught Cree children for one year at Pemmican Portage, 1948-49. Some evenings he would walk the three miles to Cumberland House to visit with the conservation officer, the Roman Catholic priest, the store manager and the RCMP constable. The next year he taught at Huxley, Alberta, before returning to Saskatoon to complete his biology degree in 1951. While teaching school at Stinson in 1951-52, Harvey was offered a job as Assistant in biology by D.S. Rawson, department head. Due to budget cuts, he was hired as Instructor and was promoted to Assistant the following year. Dr. Rawson's letter to W.P. Thompson, University president, described Harvey as "a quiet, unassuming individual."

He catalogued the insect, mammal, and plant collections at the University and realized the need for a guide to Saskatchewan mammals. His succinct, highly successful 52-page A Guide to Saskatchewan Mammals, Special Publication Number One of the Saskatchewan Natural History Society, appeared in 1958. Five thousand copies were printed and constituted a printing run much larger than that of any subsequent special 
publication; only six copies were left for sale by October 1975.

Field work in northern Saskatchewan in the summer of 1961 was directed towards a Master's thesis in mammalogy. The 119 specimens of 7 species, collected during 1370 trap nights, added to knowledge of mammal distribution and occupied 8 pages in Blue Jay 22:165-172, 1964. Harvey thought that his work showed too little promise and, to the dismay of the Biology Department, resigned from the University in April 1962.

J. D. Rempel's son Dick commented "Yes, I remember Harvey well; I instructed biology for two summers under Harvey's guidance. I recall my father's high regard and affection for Harvey, who was such a decent, informed and constructive head of the lab demonstrators in the Biology Department. Father said that everyone in the department could invariably rely on Harvey, no matter what the occasion or crisis or new development. He was extraordinarily patient, never panicked and was firm when needed." An example of this is provided by Harvey's friend, Pat Cradock. She recalls the time in the ' 60 s when Harvey was driving to Regina and hit a pregnant cow on the road. Realizing that the cow was dead, he performed an immediate Caesarian section on the spot, just before the grateful farmer arrived to take delivery of the healthy, full-term calf.

From 1962 to 1964, Harvey instructed biology at the University of British Columbia. In 1964 he returned to Saskatchewan, as a curator at the Saskatchewan Museum of Natural History for one year, and then as an instructor at the new University of Regina, 1965-67, where he taught first year biology and supervised the laboratories. While in Regina, Harvey edited and oversaw the preparation of the illustrations by staff artists for Francis Cook's Guide to the Amphibians and Reptiles of Saskatchewan (1966). Harvey then moved to Winnipeg as curator at the new Manitoba Museum of Man and Nature,
1967-69. Francis Cook was at this time working on his Ph.D. at the University of Manitoba, and appreciated the help Harvey provided him throughout his western fieldwork, which began in 1959. Harvey was also a frequent bridge-player at his home.

Harvey's final four terms of employment were as a teacher in Alberta at Calgary (1969-72), Keyano College at Fort McMurray (1973-78), Fairview College in the Peace River area (1978-81), and Old Sun College, Siksika First Nation, near Gleichen (1981-86). The First Nations people there learned of Harvey's qualifications with St. John's Ambulance, and would call him in the middle of the night to attend to injuries.

At age 59, Harvey retired to a small house on an acreage west of Strathmore, rented from the McNeill family for nearly 16 years until his unexpected death in his home on 25 January 2002.

Harvey once told his sisters that he aimed to go through life unobtrusively. This he certainly did. His major contribution to natural history was "behind the scenes." Perhaps the foremost example was the unsung, unpaid and labor-intensive task of compiling the annual index for the Canadian Field-Naturalist for volumes 93 through $105,1979-1991$. This involved preparing a separate card for each entry, many of them Latin names, and then typing them in virtually perfect typescript in alphabetic order, a joy for the typesetters of the day. As Rev. Fergus Tyson said at the memorial service at St. Michael and All Angels Church, Strathmore, "Harvey was an organized and quiet man, who led an organized and quiet life."

\section{Acknowledgements}

I extend my appreciation to all those above who offered comments, and to Cheryl Avery, who went the second mile and dug out pertinent files in the University of Saskatchewan Archives, even though they had not been indexed or catalogued. 